\title{
Research on the Reform and Perfection of Resource Tax System
}

\author{
Tingting Fan \\ Tianjin University of Finance and Economics, Tianjin, China \\ Email:2093828055@qq.com
}

How to cite this paper: Fan, T. T. (2021). Research on the Reform and Perfection of Resource Tax System. Open Journal of Social Sciences, 9, 316-328.

https://doi.org/10.4236/jss.2021.93021

Received: February 22, 2021

Accepted: March 21, 2021

Published: March 24, 2021

Copyright (c) 2021 by author(s) and Scientific Research Publishing Inc. This work is licensed under the Creative Commons Attribution International License (CC BY 4.0).

http://creativecommons.org/licenses/by/4.0/ (c) (i) Open Access

\begin{abstract}
Defining the function of resource tax is very important to promote the reform and perfection of resource tax. In this paper, the function of resource tax should be changed from "adjusting the differential income of resources" to "saving resources and promoting the sustainable use of resources". According to the functional orientation of resource tax and the development and implementation of resource tax in China, it can be analyzed that although the formulation and implementation of resource tax law is of great significance, there are still some imperfections, and if we improve the tax base, adjust the tax rate, adjust the preferential policy and income distribution mechanism, we can promote the reform of the resource tax system.
\end{abstract}

\section{Keywords}

Resource Tax, Function Positioning, Resource Tax Law, Tax Reform, Tax System Perfect

\section{Background of the Study}

Natural resources in the development process of the human material world has an indispensable position, in today's industrialization era, mineral resources as an important driving material, become an important factor restricting economic development, the Middle East oil countries can only rely on the export of oil to become rich, and resource-poor areas can only rely on imports and conservation of resources to maintain their economic development. However, in the long run, mineral resources as non-renewable resources, the amount is limited, we can now extract oil resources are tens of thousands of years ago geological changes formed, mining a little less, therefore, saving resources should become our consensus. Since the middle and late last century, various countries have formulated various policies to conserve resources and protect the environment. At the be- 
ginning of the founding of the People's Republic of China, China's mineral resources also experienced a transition from free mining to paid use. At the beginning of the founding of the People's Republic of China people's sense of saving resources is not strong, think that our country is rich in resources, the land is rich in wealth. But in fact, although China's total resources are rich, but the regional distribution is uneven, uneven structure, and low mining technology, which leads to very few per capital resources, resources supply and demand contradictions are great. Moreover, China's environmental pollution is becoming more and more serious, water resources, especially freshwater resources are decreasing sharply, and forests are constantly showing desertification, which shows that the development concept of exhaustion and fishing is not sustainable. There are serious problems in the exploitation of mineral resources, such as over exploitation and misuse of resources (Cai, 2009). All these hinder the sustainable development of Chinese society.

China's current economic growth model has caused a great waste of mineral resources, mainly manifested in the following two aspects: First, the economic development process of the increase in demand for mineral resources, so that resource-based enterprises driven by the interests of a large number of resources for destructive development. Second, because China's resource tax system is not perfect, with other taxes coordination capacity is insufficient, such as after processing the link did not levy consumption tax and low value-added tax rate, so that resources in the development and utilization stage of the tax burden is not high, resulting in low cost of resource extraction, low cost makes the cost of waste of resources is very small, so there is a serious waste in the process of resource utilization. In view of this, the government should play a role in using economic means to minimize the damage to resources and the environment.

Based on the above analysis, our government is deeply aware of the scarcity and importance of resources, and actively promotes the reform of resource tax to play the role of resource tax in conserving resources and protecting the environment. Since the introduction of the Regulations of the People's Republic of China on Resource Tax in the 1980s, although to a certain extent, the waste of resources has been curbed, but because of the narrow scope of collection, the tax basis is not perfect and many problems exist in the process of collection and management, hindering the effectiveness of resource tax should be played, need further reform and improvement (Yang, 2011), such as clear functional positioning of resource tax, expand the scope of taxation, improve the basis of taxation, in order to achieve the goal of promoting sustainable social and economic development.

The first part of this article is a background introduction, the second part analyzes and determines the functional positioning of the resource tax under the current background, the third part introduces the reform process and development changes of the resource tax, the fourth part points out the shortcomings of the resource tax, the fifth part Some suggestions for improvement are put forward for the shortcomings of resource tax, and the sixth part is a general sum- 
mary of the full text.

\section{Functional Positioning}

The role of taxation mainly focuses on adjusting income differences and raising fiscal revenue, while resource tax, as a specific purpose tax, also plays a unique role in resource conservation and environmental protection. The following from the functional positioning of taxation and the specific purpose of resource tax to analyze one by one to determine the functional positioning of China's resource tax.

\subsection{Adjusted Differential Income}

For a long time, China's resource tax is mainly located in the adjustment of resource-level differential income. First, because we are deeply influenced by Marx's ground rent theory, and secondly, because of the reality of our country, our country is rich in land, the resource structure and resource reserves in different regions are very different. In order to narrow the differences caused by resources in the eastern and western regions, China has made the adjustment of resources due to congenital conditions and structural differences as the main purpose of the 1984 resource tax regulations. China's resource tax in 1994, 2005, 2010, 2016 has undergone several adjustments, but the resource tax adjustment of resource-level differential income function positioning has not changed.

\subsection{Organization of Fiscal Revenues}

Since the introduction of the resource tax, its income as a proportion of total tax revenue has been not high, not even more than $1 \%$, so the role of organizational revenue is very limited. Moreover, because the resource tax is calculated from the measure, it has a certain regression, so the resource tax also appeared the phenomenon of tax burden reduction. Even with the nationwide reform of the resource tax in 2011, which changed from a measured tax to a price-based tax, its ability to organize fiscal revenue, although improved, was not significant. In fact, the reform and adjustment of China's resource tax is not aimed at improving fiscal revenue, throughout the world, the proportion of resource tax in fiscal revenue is generally not high. Moreover, the limited quantity of mineral resources is non-renewable, and with the continuous exploitation, the quantity will be less and less, as an important source of fiscal revenue is unsustainable, therefore, the resource tax should not be used as the main source of revenue raising.

\subsection{On Protecting the Environment}

In the process of resource development, environmental damage will inevitably be caused, such as the destruction of the surrounding ecological environment in abandoned mining areas, so some scholars think that the environmental damage in the mining process should be solved through resource tax. From the theoretical basis of resource tax levy, we can see that the external theory shows that taxa- 
tion can internalize external costs, thus promoting resource extraction enterprises to reduce the damage to the environment. However, in reality, there is no quantitative index to distinguish how much damage to the environment caused by resource exploitation, after all, the destruction of the environment in a region is not only caused by the exploitation of resources, but also may be caused by chemical and manufacturing enterprises, and, on the issue of environmental protection, China has specifically introduced environmental protection tax law, as early as 2018 began to implement. Therefore, environmental protection should not become the main function of the resource tax law.

\subsection{On Resource Conservation}

The current resource tax law should focus on promoting the function of resource conservation (Lu, Li, Rui et al., 2016). China's White Paper on Population, Resources, Environment and Development in the 21st Century, includes the content of sustainable development, "to promote generational equity, promote the harmonious coexistence of mankind and nature, and do not leave future generations without resources available." The non-renewable nature of resources makes the consumption of resources by modern people inevitably affect the use of resources by future generations. Therefore, for the benefit of future generations, we should conserve resources and promote their sustainable use. The generational negative externalities caused by the over exploitation and use of resources in our contemporary times should be regulated by the government through the collection of resource tax (Ji, 2007), because the government uses tax measures to adjust the cost, efficiency and effect in saving resources and environmental protection.

\section{The Course of Reform}

\subsection{Changes in the Resource Tax System}

From the earliest stage of free mining, to the establishment and implementation of the resource tax law in 2020, the resource tax system has undergone several changes. From the beginning to encourage the exploitation of resources to promote the development of industrialization, to later adjust the level of differential income of resources to the present conservation of resources, to promote the sustainable use of resources, the legislative concept of resource taxes and fees is constantly adjusting with the development of the times (Zhou \& Zhang, 2015). At present, saving resources, improving the efficiency of resources, preventing over exploitation of resources has become the main purpose of the resource tax law, the resource tax law is also in the continuous improvement of more and more legal, standardized.

\subsubsection{Unpaid Mining Phase}

From the beginning of the founding of the People's Republic of China to 1986, China's natural resources have been in the stage of free exploitation. First, be- 
cause of our traditional understanding of Marx's political economy at that time, we believe that resources can be used by the whole public free of charge, and second, because the level of industrialization in China is not high at that time, the free exploitation of resources can promote the development of industrialization. Although this played a positive role at that time, but obviously the negative effect is greater, because the government lacks the necessary restraint mechanism for resource-based enterprises, resulting in the over exploitation of resources and low use of resources, is not conducive to resource conservation and sustainable use of resources.

\subsubsection{The Embryonic Stage of Paid Mining}

In 1982, China promulgated the Regulations of the People's Republic of China on Foreign Cooperation in the Exploitation of Offshore Oil Resources, which did not end until the period of free exploitation. The regulation stipulates that enterprises involved in cooperative exploitation of offshore oil resources shall pay taxes in accordance with the law, which is the embryonic stage of the consciousness of state-owned paid exploitation of resources.

\subsection{The Evolution of the Resource Tax System}

The main reform course of China's resource tax can be found in the Table 1 below.

Table 1. The evolution of the resource tax system.

\begin{tabular}{|c|c|c|}
\hline Start time & Policies and regulations & Contents of legislation \\
\hline October 1984 & $\begin{array}{l}\text { The People's Republic of China Resource Tax Law } \\
\text { (Draft) }\end{array}$ & $\begin{array}{l}\text { Tax coal, oil and natural gas resources, sales revenue as the tax base, } \\
\text { the implementation of excess rate progressive collection. }\end{array}$ \\
\hline January 1986 & $\begin{array}{l}\text { Law of the People's Republic of China on Mineral } \\
\text { Resources }\end{array}$ & $\begin{array}{l}\text { Start paid mining mineral resources, but also formed the coexistence } \\
\text { of resources taxes and fees. }\end{array}$ \\
\hline January 1994 & $\begin{array}{l}\text { Interim Regulations of the People's Republic of China } \\
\text { on Resources Tax }\end{array}$ & $\begin{array}{l}\text { Salt tax incorporated into resource tax; tax extended to include other } \\
\text { non-metallic ore deposits, ferrous ore deposits, non-ferrous metal ore } \\
\text { deposits, etc }\end{array}$ \\
\hline June 2010 & $\begin{array}{l}\text { Provisions on Some Problems in the Reform of Crude } \\
\text { Oil and Natural Gas Resources in Xinjiang }\end{array}$ & $\begin{array}{l}\text { The tax on crude oil and natural gas resources is collected by ad } \\
\text { valorem in Xinjiang, and the tax rate is } 5 \% \text {, which is the step from } \\
\text { volume tax to ad valorem tax in our country }\end{array}$ \\
\hline November 2011 & $\begin{array}{l}\text { The Decision of the State Council on the Amendment } \\
\text { of the }><\text { the Interim Regulations of the People's } \\
\text { Republic of China on Resources Taxation }\end{array}$ & $\begin{array}{l}\text { Taxes on crude oil and natural gas are calculated on an ad valorem } \\
\text { basis from } 5 \% \text { to } 10 \% \text { of sales volume, with individual adjustments to } \\
\text { the range of tax rates levied on the ad valorem basis }\end{array}$ \\
\hline October 2014 & $\begin{array}{l}\text { Circular of the Ministry of Finance and the State } \\
\text { Administration of Taxation on the Adjustment of the } \\
\text { Policy on Tax on Crude Oil and Natural Gas Resources }\end{array}$ & $\begin{array}{l}\text { Adjust the applicable tax rate for crude oil and natural gas resources } \\
\text { from } 5 \% \text { to } 6 \% \text {; and December } 2014 \text { Circular of the Ministry of } \\
\text { Finance and the State Administration of Taxation on the } \\
\text { Implementation of the Reform of Coal Resources Tax Implementation } \\
\text { of the nationwide coal resources tax levying reform, while cleaning up } \\
\text { related fees and funds }\end{array}$ \\
\hline May 2015 & $\begin{array}{l}\text { "Ministry of Finance, State Administration of Taxation } \\
\text { on the implementation of rare earth, tungsten, } \\
\text { molybdenum resources tax ad valorem levy reform" }\end{array}$ & $\begin{array}{l}\text { RE, W, Molybdenum Resources Tax changed from Volume Quota to } \\
\text { Price Quota }\end{array}$ \\
\hline
\end{tabular}




\begin{tabular}{|c|c|c|}
\hline May 2016 & $\begin{array}{l}\text { Circular on comprehensively advancing the reform of } \\
\text { resource tax }\end{array}$ & $\begin{array}{l}\text { Through the comprehensive implementation of the reform of clearing } \\
\text { fees and levying taxes, straightening out the relationship between } \\
\text { resources taxes and fees, and establishing a fair, reasonable and efficient } \\
\text { resource tax system, the pilot reform of resource tax levying and water } \\
\text { resources tax reform has been implemented since July 1, } 2016 \text {. }\end{array}$ \\
\hline August 2019 & Resources Tax Law of the People's Republic of China & $\begin{array}{l}\text { The resource tax shall be calculated from the price or from the } \\
\text { measure in accordance with the Tax Item Tax Rate Table. Where a } \\
\text { levy is applied from the price, the taxable amount shall be calculated } \\
\text { according to the sales of taxable resource products multiplied by the } \\
\text { applicable tax rate. Where a measure is applied, the taxable amount } \\
\text { shall be calculated according to the quantity of sales of taxable } \\
\text { products multiplied by the specific applicable tax rate. Effective } \\
\text { September } 1,2020\end{array}$ \\
\hline
\end{tabular}

Data source: official website of the State Administration of Taxation.

\section{The Shortcomings of the Resource Tax Law}

\subsection{The Scope of Taxation Is Too Narrow}

The current resource tax covers only energy minerals, metal minerals, non-metallic minerals, water vapor minerals and salt and other mineral resources (The Resource Tax Law of the People's Republic of China). However, from the basic theory of resource tax, resource tax should include all natural resources in nature, not just mineral resources. The scope of resource taxation is too narrow, which is contrary to the principle of fair taxation to a certain extent. Natural resources, such as forests, grasslands and minerals, and some natural resources need to pay taxes, some natural resources do not need to pay taxes, because some resources are alternative, which will result in non-taxable natural resources are not protected, wanton exploitation and use, can not improve the efficiency of resource use, and can not play the role of resource tax to save resources and protect the environment.

\subsection{The Basis for Taxation Is Unscientific}

China's newly promulgated resource tax law stipulates: "Resource tax in accordance with the 'tax item tax rate table' to implement ad consideration or from the measure." The Tax Item Tax Rate Table provides that ad consideration or accrual may be chosen in accordance with the actual situation, and if ad consideration is applied, the taxable amount should be equal to the amount of resource sales multiplied by the applicable tax rate. From this regulation, it can be seen that, although China's resource tax collection method has been changed to the actual situation to choose the implementation of price-based or quantitative levy, but the amount of resource tax is equal to the amount of resource sales multiplied by the applicable tax rate (The Resource Tax Law of the People's Republic of China). Rather than the actual amount of exploitation, which will cause a lot of waste in the exploitation and utilization of resources, is not conducive to the intensive development of resources, is not conducive to improving the comprehensive utilization rate of resources. 


\subsection{Too Many Preferential Policies}

In China's resource tax law can see a lot of tax relief preferential policies. For example, the exemption is for crude oil and natural gas used for heating and consumption in the process of extracting crude oil. This can reduce the tax burden of enterprise resource tax, and also encourage enterprises to improve mining technology and increase resource utilization. But at the same time, there are some negative effects. First of all, it is not conducive to tax fairness, because tax benefits are only available to a few people, and some enterprises in order to enjoy the tax benefits should not have falsely declared and money rights transactions, which caused great unfairness to other taxpayers. Second, it is not conducive to the effective allocation of resources, tax incentives make government policies tilted in favor of enterprises that can enjoy preferential policies, which will make these enterprises cheaper, faster development, and those who can not enjoy preferential enterprises because of high cost pricing will be marginalized in the market. Once again, preferential policies objectively stimulate enterprises to enjoy preferential policies to develop resources in order to enjoy as many concessions as possible, resulting in waste of resources and low rate of return of resources, and the purpose of the resource tax is to save resources, promote the sustainable use of resources rather than excessive exploitation of resources.

\subsection{Repeated Taxes and Fees}

China's newly promulgated resource tax law stipulates that the collection of water resources tax, stop the collection of water resources fees (The Resource Tax Law of the People's Republic of China). In fact, there has always been a problem of the existence of taxes and fees in China's resource tax reform. First of all, the overlap of taxes and fees makes the corporate tax burden very unreasonable. For example, some local charges are numerous, and these charges are largely similar to the resource tax collection function, which will cause the overlap of resource taxes and fees, increase the production costs of enterprises, increase the burden on enterprises, not conducive to the development and transformation of enterprises. For example, the mineral resource compensation fees collected in the process of resource mining converge with the resource tax, which not only violates the positioning of the resource tax, but also actually overlaps with the basis for the collection of mineral resource compensation fees, resulting in no distinction between taxes and fees. Secondly, it will form the phenomenon of "fee squeeze tax", a large number of extra-tax expenses reduce the status of resource tax, is not conducive to the construction of resource tax system. Again, different tax collection and management methods and management methods will also increase the cost of collection and management, resulting in inefficient government administration, waste of personnel, unreasonable administrative structure and so on.

\subsection{The Allocation Mechanism of Resource Tax Is Unreasonable}

In the 94-year tax-sharing reform, China has made a clear division of tax power, 
which stipulates that the tax revenue according to the administrative authority is divided into central tax, local tax and shared tax. Among them, the resource tax belongs to the central local shared tax, except for the marine oil and gas resources tax owned by the central government, other resources tax belongs to the local government. This income distribution mechanism played a positive role at that time, such as increasing local fiscal revenue, alleviating local fiscal tension, but also played a certain role in regulating and narrowing the income gap between regions. However, with the development of society, the concentration of resource tax power is not conducive to mobilizing the enthusiasm of local governments (Liu, 2010). Although the resource tax belongs to the central local shared tax, except for the marine oil and gas resources tax owned by the central government, other resources tax belongs to the local government, however, the local government only a small part of the taxable mineral products tax object and tax rate has the right to determine, the vast majority of taxable resources are still determined by the central government, which is not conducive to the local government to adjust the resource level differential income and promote resource conservation, can not mobilize the enthusiasm of local governments, but also limit the role of resource tax regulation and promote resource conservation.

\section{Reform Proposals}

\subsection{Expand the Scope of the Resource Tax}

The current resource tax only covers mineral resources, and the scope of future resource tax reform should be further extended to forests, grasslands, beaches and other natural resources (Chen, 2018). First of all, we should carry out the pilot work of water resource tax reform. Because water resources are closely related to people's lives and affect all aspects of society, they should be carried out in Beijing, Tianjin, Shanxi, Inner Mongolia Autonomous Region, Shandong Province, Henan Province, Sichuan Province, Shaanxi Province and Ningxia Hui Autonomous Region in a gradual manner. On the basis of summing up the pilot experience, it can be further pushed away from the point and face, to find the right time, can be widely promoted throughout the country, in order to strengthen people's awareness of water conservation. Second, to gradually include other natural resources in the scope of taxation, such as forests, grasslands and minerals, belong to natural resources, only mineral resources are taxed, and some natural resources are not taxed, because some resources are alternative, which will result in the non-taxable natural resources are not protected, wanton exploitation and use, is not conducive to improving the utilization of resources, and can not make resource taxes give full play to the role of resource conservation and environmental protection, so local governments should be based on different regions of forests, grasslands, Beach and other resources development and utilization of different circumstances to put forward specific recommendations, according to local conditions, accurate policy. 


\subsection{Improve the Basis of Resource Tax}

Under the background of resource shortage and resource price increase, although the collection method of resource tax in our country has changed from a single measure to a price-based levy according to the actual situation, the calculation of resource tax is based on sales volume rather than mining volume, which will cause a lot of waste in the exploitation and utilization of resources (Announcement of the State Administration of Taxation on Several Issues Concerning the Collection and Management of Resource Tax). Resource taxes should not be calculated by sales volume alone, which does not reflect the costs and utilization of resources that resource extraction companies pay for their exploitation of resources. After the change to price, not only increase the enterprise resource tax to improve the awareness of saving resources, but also help to narrow the income gap between East and West. However, from the measure tax or from the price tax also need specific analysis, such as the current resource tax law from the measure of gravel can be timely to promote the price of the levy, and the main consumption object of salt is individuals and residents, demand is relatively stable, price fluctuations are relatively small, so we can take the method of measured.

\subsection{Adjust the Rate of Resource Tax}

The main purpose of resource tax is to save resources, in order to reflect the scarcity of resources, promote the economy consciousness of enterprises, the tax rate of resource tax plays an important role in it. If the resource tax rate is low, it will lead to low cost of resource exploitation, and it is difficult for enterprises to realize the value of resources, which is not conducive to resource conservation and rational use (The Resource Tax Law of the People's Republic of China (Draft)). In addition, resource tax rates should be differentiated, different resource tax rates should be differentiated, and high taxes on particularly scarce resources could strengthen the protection of scarce resources. Different regions due to the differences in the initiative conditions of resources and mining conditions, should also be distinguished, so that local conditions to better play the role of resource tax regulation. The preferential tax policy of resource tax is also closely related to the tax rate of resource tax, and many of the preferential policies of resource tax involve the reduction of resource tax rate, which can also encourage the recycling of resources and improve resource utilization efficiency and recovery rate. On the one hand, the design tax rate should take into account that the tax rate level should reflect the marginal cost of resource exploitation to the maximum extent, so as to achieve external cost internalization, on the other hand, we should also take into account that the tax rate should be levied difference but not too much, too many levels will increase the complexity of the tax system, leading to corruption and increase the cost of collection.

\subsection{Adjust the Resource Tax Preferential Policy}

As for the preferential policy of resource tax, there are two views in the academic 
circles. One is that tax incentives should be increased, because they can reduce the tax burden of some enterprises, promote the development and transformation of enterprises, and give preferential treatment to resources that are difficult to exploit, costly and have low overall utilization, which can improve the efficiency of resource utilization. The other view is the opposite, that preferential policies should be reduced, because tax incentives are contrary to the principle of tax fairness, some resources are taxed, and some resources can be tax relief, not only not conducive to the adjustment of resource tax, but also not conducive to the effective allocation of resources. The author believes that China's existing resource tax preferential policies should be adjusted according to the actual situation in a timely manner. Too many preferential tax policies will undoubtedly increase the complexity of the tax system, complex tax system will breed corruption and unfairness, and will increase the difficulty of tax collection and management, waste unnecessary human and financial resources, can not achieve the goal of perfecting the tax system and improving the efficiency of tax collection and management. Of course, this is not to say that the tax incentives should be abolished completely, but that the appropriate preferential tax policies will promote the utilization of abandoned mining areas and mineral resources. Therefore, according to the actual situation, timely adjustment, the elimination of backward and unnecessary preferential tax policies.

\subsection{Tax Consolidation}

China's newly promulgated resource tax law mentions that the collection of water resources tax, stop the collection of water resources fees (Cai, 2009). The overlap of taxes and fees not only makes the enterprise tax burden very unreasonable, increases the production cost of the enterprise, is not conducive to the development of the enterprise, but also forms the phenomenon of "fee squeeze tax", a large number of extra-tax expenses reduce the status of the resource tax, is not conducive to the construction of the resource tax system, the different ways of collection and management of taxes and fees will also increase the cost of collection and management, resulting in inefficient government administration, waste of personnel, unreasonable structure and so on. Therefore, this paper holds that the resource tax should be collected jointly, with the tax substitute fee, and the resource-related charges should be unified into the resource tax, and be collected and managed by the inland tax bureau. On this basis, we have established a resource tax system that can adapt to China's economic development and promote the sustainable development of our economy, and the forest resources, grassland resources, beaches and other natural resources other than mineral resources will be unified income and resources tax system, no longer collected by other departments in the form of fees.

\subsection{Adjust the Allocation System of Resource Tax}

China's resource tax is al shared tax, of which marine oil and gas resources tax owned by the central government, while other resources tax belongs to the local 
government. This income distribution mechanism makes the resource tax power concentrated, which is not conducive to mobilizing the enthusiasm of local governments. Although in addition to the marine oil and gas resources tax to the central government, other local governments, however, the local government only a small part of taxable mineral products tax object and tax rate has the right to determine, most taxable resources are still levied by the central government, which is not conducive to mobilizing local governments' enthusiasm for adjusting resource differential income and conserving natural resources, but also limit the role of resource tax regulation and promote resource conservation. Therefore, this paper holds that since the resource tax as a local tax there are many problems, it should be as a central tax, by the tax bureau unified collection and management, and then the national overall adjustment. That is, establish a special resource tax special fund mechanism, and the income from resource tax is mainly used for the construction of local resources saving, to support local resource enterprises to improve resource extraction technology and resource utilization efficiency. At the same time, we can further establish a standardized financial transfer payment system and effectively supervise the use of special funds.

\subsection{Coordination of Resource Taxes with Other Taxes}

Because of the small proportion of resource tax, it plays a limited role in resource conservation in society. Therefore, we should coordinate the resource tax with other taxes, establish a perfect resource tax system, since the purpose of resource tax is to save resources, we should coordinate with other taxes to play the role of saving resources. For example, China's resource processing enterprises after processing, only a part of the resources to levy consumption tax, most of the resources in this link consumption tax is missing, and the value-added tax collection tax in this link is also very low, and can not serve as a wake-up call to save resources, therefore, the need for other taxes supporting coordination. As far as consumption tax is concerned, it is necessary to increase the consumption tax and levy consumption tax on some scarce resources. As far as value-added tax is concerned, it is possible to strictly manage the collection and administration of value-added tax in this link, and to plug the loopholes in the collection and management. As far as environmental tax is concerned, it can be strictly managed on the resources that cause great resource consumption and environmental damage in the process of exploitation, curb its destruction and waste, and improve the technology and level of resource exploitation (Luo, Zhang, \& Xiao, 2013). If the resource tax wants to play the goal of saving resources, it is necessary to establish a coordinated system of multiple taxes, integrate it into the mechanism of resource conservation and environmental protection, and reform and perfect it.

\subsection{Simple and Optimize the Process to Effectively Reduce the Burden}

After the implementation of the resource tax law, the tax period of resource tax 
shall be adjusted to monthly or quarterly, and the reporting period shall be adjusted from 10 days to 15 days. This can reduce the frequency of taxpayers' declarations and objectively reduce the cost of taxpayers' pursuit.

In the process of resource tax reporting, the new resource tax tax return consists of only one main form and one schedule, which also greatly reduces the workload of the financial personnel of the enterprise, saving the taxpayer's tax time and cost. In addition, we should promote the linkage between tax departments and other departments, such as tax departments should also establish work linkage with the Environmental Protection Bureau, meteorological bureau and other relevant departments, and some social institutions to establish data sharing mechanism, in order to improve the quality of resource tax risk prevention and control, strengthen the supervision and management of resource extraction enterprises, and better promote the implementation of the resource tax law.

\section{Conclusion}

The above research can be concluded that the functional orientation of resource tax should be changed from "regulating resource-level differential income" to "saving resources and promoting the sustainable use of resources". According to the functional orientation of resource tax and the development course and implementation status of resource tax in China, it can be analyzed that although there are still some shortcomings in the current resource tax law, its establishment and implementation still have great legislative and practical significance. On the one hand, in line with our current advocacy of the green tax system, after all, the natural environment of green water green mountains than mountain made money more precious, resource tax on the waste of resources and ecological damage has a certain positive role. China's environmental protection tax law is the first step in the transformation of China's green tax system; resource tax should follow closely, with other taxes such as value-added tax, consumption tax, together to build a green tax system, the use of tax levers to encourage green economic development, towards the goal of sustainable development. On the other hand, although China's total resources are abundant, but uneven regional distribution, and low mining technology, which leads to very few per capital resources, in order to alleviate the contradiction of resource tax shortage, this paper believes that the resource tax law should be used to improve the efficiency of resources, and optimize resource allocation. In addition, the introduction of the resource tax law will improve the cost of resource utilization, the corresponding will also improve people's awareness of saving resources, objectively encourage some resource-consuming enterprises to improve the level of resource exploitation, improve the efficiency of the use of resources or the use of new energy, promote the transformation and upgrading of enterprises.

The practical significance of this article is that although the resource tax reform has a limited ability to increase tax revenue on the whole, it conveys the 
value orientation of cherishing resources, saving resources, and caring for the environment to the whole society, which is conducive to my country's resourcesaving and environmentally friendly The establishment of a society is conducive to strengthening the concept of advocates for a low-carbon economy and caring for the global climate, and promotes sustainable social development. Of course, due to the limited level of the author, the discussion on resource tax is not very in-depth. For example, regarding the shortcomings of resource tax, we can only point out the shortcomings from a more macro perspective, but the shortcomings in the specific operation are not understood and improved. The feasibility of the proposal and the negative impact of the improvement proposal are also uncertain. The resource tax reform still needs more in-depth research.

\section{Conflicts of Interest}

The author declares no conflicts of interest regarding the publication of this paper.

\section{References}

(2019). Resources Tax Law of the People's Republic of China. Order No. 33 of the President of the People's Republic of China.

Announcement of the State Administration of Taxation on Several Issues Concerning the Collection and Management of Resource Tax.

Cai, X. Y. (2009). Energy Tax System in China: Status, Problems and Possible Solutions. Taxation Research Journal, No. 7, 16-20.

Chen, Z. D. (2018). The Evolution Path and Development Direction of China's Resource Tax Policy: A Study Based on Policy Texts at the National Level from 1982 to 2016. Comparison of Economic and Social Systems, No. 1, 63-69.

Exchange Law Network. The People's Republic of China Resource Tax Law (Draft). http://lawxp.com

Ji, J. B. (2007). A Brief Discussion on the Position of National Resource Tax and Its Position in Tax Reform. Taxation Research, No. 11, 36-40.

Liu, S. X. (2010). A Resource Tax Reform Should Position Control of Public Risks. China Development Watch, No. 7, 11-12.

Lu, Z., Li, S., Rui, D. et al. (2016). A Reform of Resource Tax System: Reflections on Function Orientation. China Tax Research, No. 5, 72-75.

Luo, N. S., Zhang, X., \& Xiao, L. L. (2013). A Study on the Long-Term Influence of Resource Tax Reform on the Development of Mineral Resources Industry in China. Economic Geography, 33, 123-129.

Yang, Z. Y. (2011). Taxation and Fee Reform: Ideas and Trends. Foreign Tax, No. 8, 8-11.

Zhou, Z. B., \& Zhang, W. G. (2015). A Study on Evolution History and Reform Path of China's Resource Tax System. Macroeconomic Research, No. 9, 49. 